\title{
ESTIMATE AND MAPPING SALINITY DISTRIBUTION IN SOME SOILS OF EGYPT BY USING ELECTROMAGNETIC INDUCTION INSTRUMENT
}

\author{
R. K. Yacoub(1), M. S. Amira(2), F.E. Abu-Agwa(2), M. Ismail(1), \\ E. A. Abou Hussien(2) and W.M. Abou El Nour(1). \\ (1) RS and GIS Unit, Soils, water, and Environment Research Inst., Agric. Res. Center, Giza \\ (2) Soil Sci. Dept., Fac. of Agric., Menoufia Univ. Shebin El-Kom, Egypt. \\ Received: May. 9, 2019 \\ Accepted: Jun. 1, 2020
}

\begin{abstract}
Remote sensing techniques such as electromagnetic induction (EMI), and electric resistivity are recently used to study soil salinity, water table depth and soil mineralogy in the field. Electromagnetic induction (EMI) is a useful mean of assessing soil salinity in the large areas, particularly after its calibration on different soils. The aim of this work is to estimate and mapping soil salinity distribution for some soils of Egypt by using EMI 400 instrument.

Three Egyptian soil parts were chosen for this study from saline and non-saline calcareous soils in EI Nubaria area as well as sandy soils in El Sadat area. EMI $\mathbf{4 0 0}$ instrument was used to predict, record and calculate the salinity in the field using three frequency bands of 14,15 and $16 \mathrm{KHz}$ for these parts. On the other hand, soil samples were collected from the surface and subsurface layers of these parts for determining salinity in the lab using EC meter apparatus. The correlation between the EMI readings and the lab determined EC values were statistically analyzed and results could be summarized in the following:

The statistical analyses indicated that, there are a highly significant correlation coefficients between EMI readings at the three frequency bands and the lab determined ECe values of each layer in all studied parts. The highest correlation coefficients were found with the EMI readings at $15 \mathrm{KHz}$.

Moreover, multi factorial as well as simple regression equations were derived from the statistical analyses to calculate the soil salinity (ECc) from EMI readings in the field. The most suitable equation for calculating soil ECC was that based on instrument readings at frequency band $15 \mathrm{KHz}$ alone.

Spatial salinity distribution maps were produced and presented for both surface and subsurface layers of the studied parts whether based on lab determined ECe or calculated ECc from EMI instrument readings.
\end{abstract}

Key words: Remote sensing, electromagnetic induction (EMI), soil salinity, ECe, sandy soil, calcareous soil, regression equation.

\section{INTRODUCTION}

Soil salinity caused by natural or human-induced processes is a major environmental hazard. Soil survey including laboratory analysis is historically the useful way to collect and determine knowledges about soil salinity and its intensity. Recently, Remote sensing techniques especially proximal sensors such as electromagnetic induction (EMI), and electric resistivity are used to study soil water content, salinity, clay content and mineralogy, bulk density, and porosity in the field. Electromagnetic induction (EMI) is a useful mean of assessing soil salinity in the large areas, particularly after its calibration on different soils. 
Wollenhaupt et al. (1986) suggested a method for calibrating electromagnetic induction instrument readings with saturated paste determined electrical conductivity (ECe) for field mapping purposes. They concluded that, the determined ECe values were correlated with the apparent soil electric conductivity (ECa) from the electromagnetic induction instrument by a simple linear regression. This technique is designed for soil association of similar parent materials. The resulting regression equation yields a quick reliable equation that avoids complex mathematics and converts the instrument readings into weighted forms of commonly used saturated paste electrical conductivity values.

Priori et al. (2010) studied the comparison between three different proximal sensors to delineate soil boundaries and estimate ECa, clay and skeleton content in a vineyard of the Chianti region (Central Italy). These sensors were: geoelectric system (Automatic Resistivity Profiling, ARP), a single-frequency electro-magnetic induction sensor (EMI, Geonics EM38-DD) and a multi-frequency EMI sensor (GSSI Profiler EMP- 400) in different configurations. All three sensors produced ECa maps with similar pattern. The strongest correlations between the instruments were between ARP and EM38_HDD as well as ARP and Profiler EMI. The correlations between ECa and clay content calculated on the fine earth were strong with ARP. The correlation improved and result significant for all the sensors when the percentage value of clay was referred to the whole soil (fine earth + skeleton).

Saksa, P. and Sorsa, J. (2016) reported that, direct current electrical methods have been used for a long time in groundwater investigations. New versatile electromagnetic induction (EMI) based instruments have also recently been made available. They particularly offer suitability to fast near-surface mapping of electrical resistivity and soundings in the depth range of $0-15 \mathrm{~m}$. Instruments also suit to varying ground conditions. Integrated use with ground-radar (GPR) offers improved discrimination of soil layers and their electrical properties. Development work has included methodological tests as well as stability and calibration studies have been important part of the EMI development. Results show that change detection down to $\mathbf{5 0}-\mathbf{1 0 0} \mathbf{p p m}$ in total dissolved solids (TDS) content in groundwater is possible. This is exemplified with calculations made for hand-held EMI system (GSSI system EMP-400 Profiler) and for groundwater layer at depth of $3.0 \mathrm{~m}$ from the ground surface.

Martini (2017) reported that, electromagnetic induction (EMI) measurements are widely used for soil mapping, as they allow fast and relatively low-cost surveys of soil apparent electrical conductivity (ECa). Although the use of non-invasive EMI for imaging spatial soil properties is very attractive, the dependence of ECa on several factors challenges any interpretation with respect to individual soil properties or states such as soil moisture $(\theta)$. They found that, stable soil properties can be the major control of ECa measured with EMI depending upon site characteristics. Further, his study discusses the complex interplay between factors controlling ECa and $\theta$, and the use of EMI-based ECa data with respect to hydrological applications.

The aim of this work is to measuring and spatial mapping the soil salinity distribution for the surface and subsurface layers of three Egyptian soil parts in El Nubaria calcareous and EI Sadat sandy soils by using EMI 400 instrument. 


\section{MATERIALS AND METHODS}

\section{Study areas:}

El Nubaria and El Sadat area located at the west of Nile Delta in Egypt were chosen as studied areas for this work (Fig. 1).

\section{Materials:}

-Satellite images: a high-resolution (10 meter) multispectral imager Sentinel-2A images dated 3/11/2018 were used.

-Field work materials, such as ropes, auger, axe, plastic bags, flags, measuring tape 25 meters.

\section{Equipment's:}

-A hand-held electromagnetic induction instrument (Profiler EMI-400) was used to measure absolute readings at three frequency bands $(14,15$ and $16 \mathrm{KHz})$ indicating the soil salinity in the field.

-A Dynamic GPS to define and determine the location of the EMI 400 measurements in the field.

-Electrical conductivity meter to determine EC of soil samples in the lab according to Burt (2004).

\section{Software's:}

-Arc-GIS version 10.4.1 was used for input and analysed data.

-SPSS statistics software version 20.0 was used for statistical analysis.

-ILWIS v. 3.7 software was used to produce the spatial salinity maps.

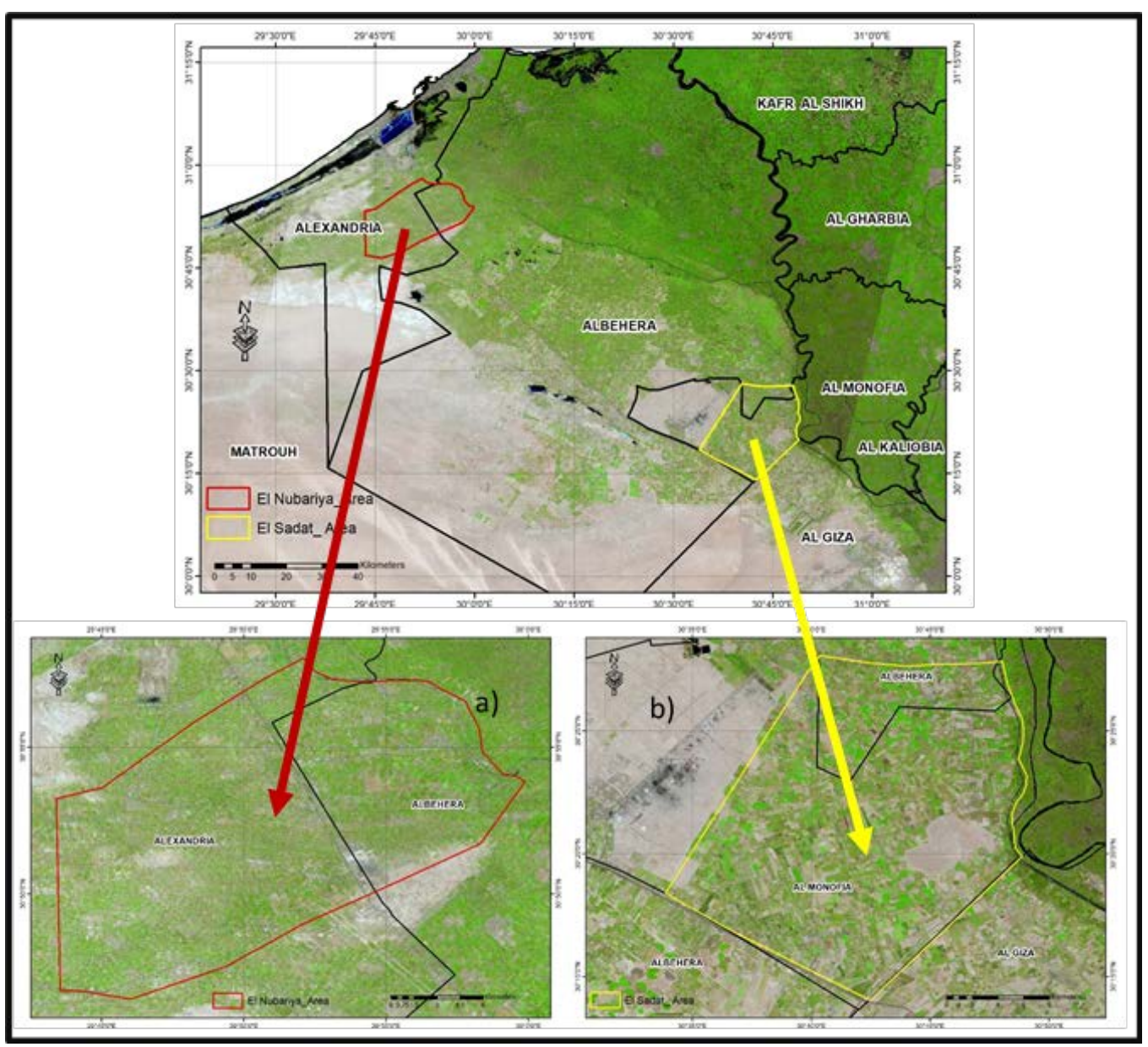

a) El Nubaria Area

b) EL Sadat Area

Fig (1): Location of the two studied areas west of Nile Delta, Egypt 


\section{Methods:}

The Map Projection: The Red built projection of the Egyptian Transverse Mercator (ETM) was applied to all the produced maps.

\section{Field work:}

Three parts were selected from El Nubaria and El Sadat areas in Egypt. These parts were: Part (1) chosen from the saline calcareous soils of EI Nubaria area (Fig, 2), Part (2) chosen from non-saline soils of El Nubaria area (Fig, 3) and Part (3) chosen from the sandy soils of EI Sadat area (Fig, 4) according to Abou EI Nour (2020). EMI readings were taken in a grid system. The grid configuration of measuring points was in orthogonal grid of an area $(30 \times 30)$ meters in the three parts. The distances between points were ( $3 \times 3)$ meters with a total number of measurements of 100 points (10 lines and 10 rows) in each part. The readings were taken using pallet carried on shoulder that keeping instrument hight of 1 meter above the soil surface. The reading of each point was taken and recorded by Profiler EMI400 using zigzag orientation. Three frequency bands $(14 \mathrm{KHz}, 15 \mathrm{KHz}$, and 16 $\mathrm{KHz}$ ) were used during the measurements. The time interval between readings is $\mathbf{2}$ seconds. The process of EMI
400 measurements was repeated three times in each point. On the other hand, 50 soil samples were collected from each of surface $(0-30 \mathrm{~cm})$ and subsurface (30 $60 \mathrm{~cm}$ ) layers representing the soils between each two reading points of each studied parts for lab ECe determination.

\section{Data analysis and maps producing:}

- The correlation between EMI readings of each parts and lab determined EC values $\left(\mathrm{dSm}^{-1}\right)$ of soil samples were statistically analysed using SPSS, version 20.0 .

- A multi linear regression equation for each studied part had educed based on the significant of the correlation analysis. The multi linear regression model was applied to calculate the ECC values using EMI readings of each part.

- The correlation between the calculated ECc values by regression equation of each part and its lab determined ECe values of soil samples were, also, statistically analysed.

- The interpolation operation of Arc GIS software was used to create the spatial salinity distribution maps of different layers using the parameters of multi regression model of each studied part.

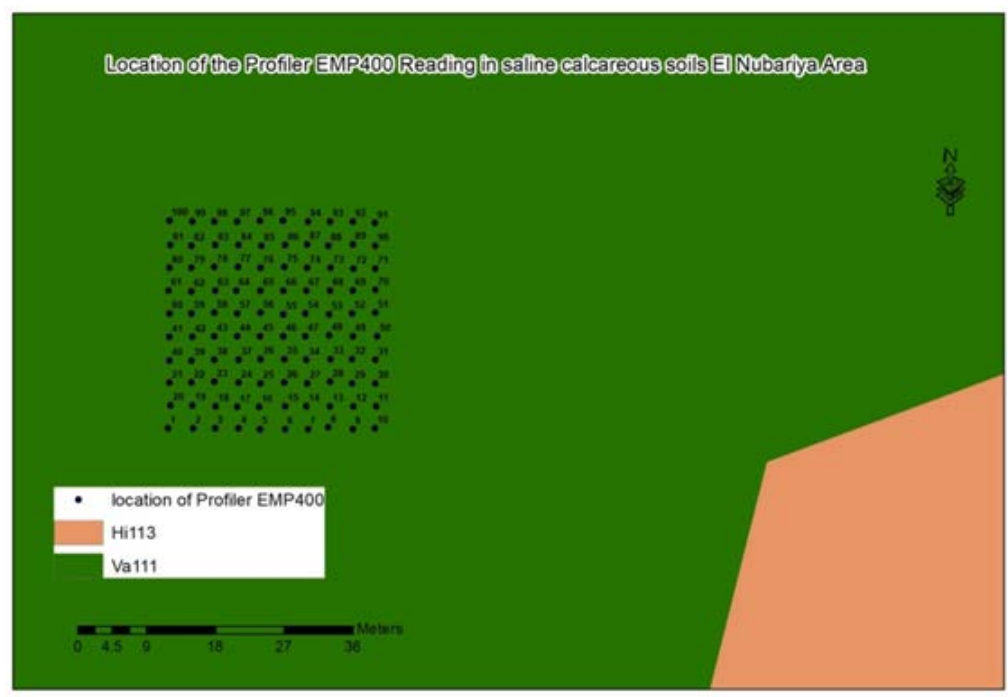

Fig (2): Points design of EMI readings in Part (1). 


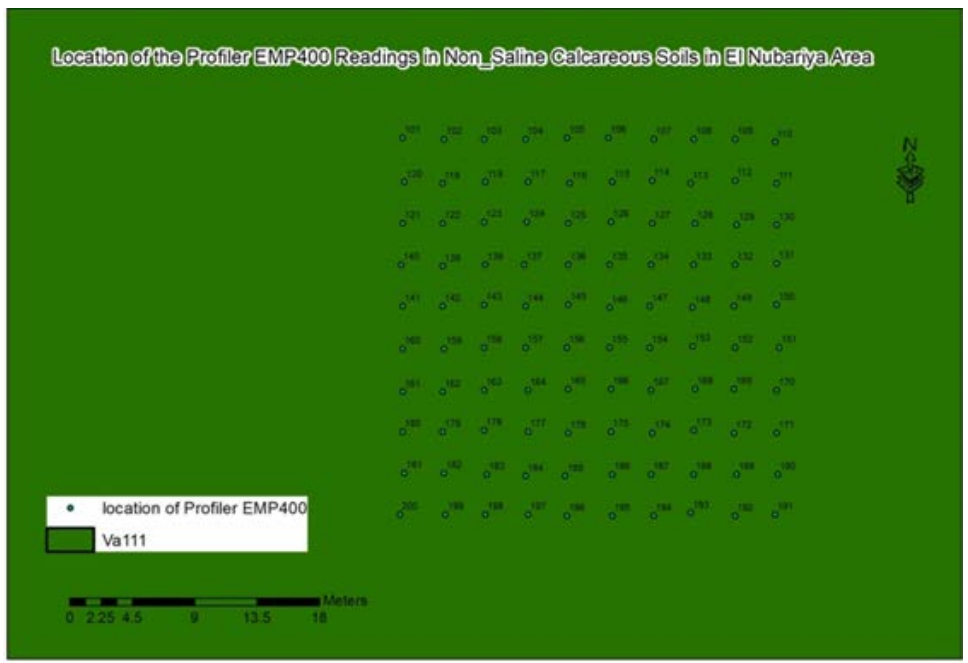

Fig (3): Points design of EMI readings in Part (2).

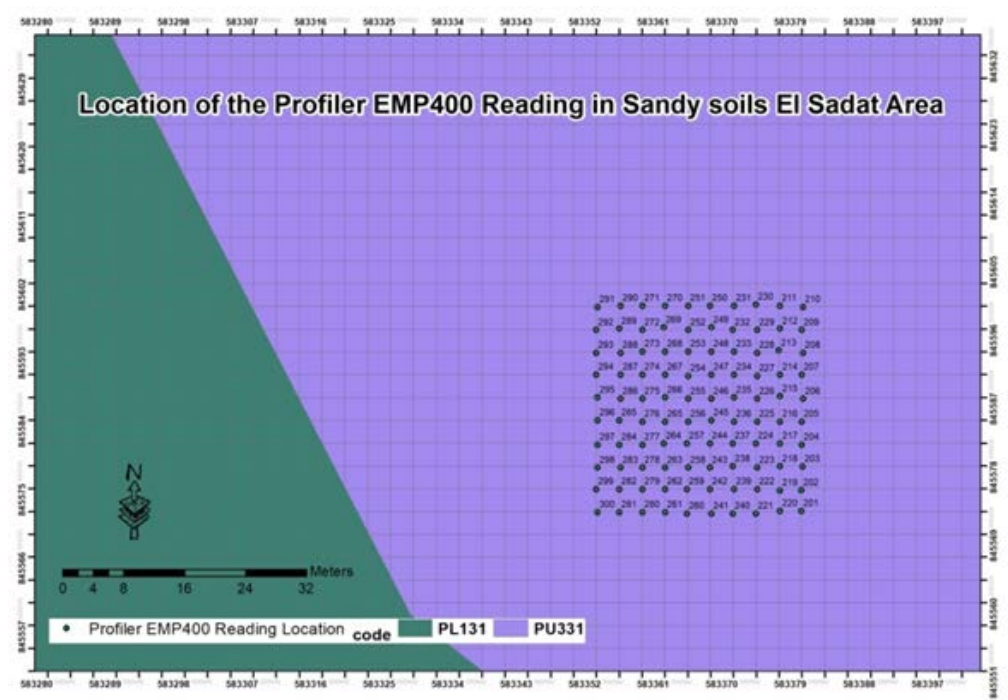

Fig (4): Points design of EMI readings in Part (3).

\section{RESULTS AND DISCUSSION}

Electromagnetic induction (EMI 400) instrument is used to measure soil salinity in the field for vertical soil layer $(0-60 \mathrm{~cm})$ of the definitive points in the three chosen parts from the studied areas. The readings of EMI instrument are measured and recorded at three frequency bands, namely, 14, 15 and $16 \mathrm{KHz}$. The correlation between these readings and lab determined ECe values for the representative soil samples of surface and subsurface layers were statistically analyzed. The results could be discussed as follows:

Producing the salinity maps of saline calcareous soils (Part, 1):

The statistical analyses of the results of this part (1) indicated that, there are a highly significant negative correlation coefficients between EMI readings at the three frequency bands and lab determined ECe values of each layer. The coefficients of the surface layer were $-0.813^{\star *},-0.845^{\star *}$ and $-0.810^{\star *}$ with bands 14,15 and $16 \mathrm{KHz}$ respectively. It could be noticed that, the 
highest coefficient for this layer $\left(-0.845^{* *}\right)$ was found with band $15 \mathrm{KHz}$. While, the coefficients of the subsurface layer were $0.794^{\star *},-0.828^{\star *}$ and $-0.795^{\star *}$ at bands 14 , 15 and $16 \mathrm{KHz}$ respectively. Also, the highest coefficient for this layer $\left(-0.828^{\star *}\right)$ was found at band $15 \mathrm{KHz}$.

Moreover, four regression equations had educed to calculate ECc values by using the readings of EMI instrument for each layer of this Part (1). The first two equations (1.1) and (1.2) are multi factorial equations based on the three EMI readings at the three bands $(14,15$ and 16 $\mathrm{KHz}$ ) for each layer as follows:

$$
\begin{gathered}
\mathrm{EC}_{\mathrm{CS} 1}(\text { Part, } 1)=79.78+2.08 \times \mathrm{R}_{14 \mathrm{KHz}}- \\
2.78 \times \mathrm{R}_{15 \mathrm{KHz}}+0.20 \times \mathrm{R}_{16 \mathrm{KHz}} \ldots . \\
(1.1) \\
\mathrm{EC}_{\mathrm{CS} 2}(\text { Part, } 1)=75.33+2.08 \times \mathrm{R}_{14 \mathrm{KHz}}- \\
2.70 \times \mathrm{R}_{15 \mathrm{KHz}}+0.17 \times \mathrm{R}_{16 \mathrm{KHz}} \ldots . \\
(1.2)
\end{gathered}
$$

Where:

$R$ is the EMI reading at the defined frequency band.

$E_{c s 1}$ is calculated EC for the surface layer.

$E C_{c s 2}$ is calculated $E C$ for the subsurface layer

The second two equations (2.1) and (2.2) are simple regression equations based on EMI reading at band $15 \mathrm{KHz}$ alone for each layer as follows:

$E_{\text {CS1 }}($ Part, 1$)=74.13-0.50 \times R_{15 K H z}$ ...(2.1)

$\mathrm{EC}_{\mathrm{CS} 2}\left(\right.$ Part, 1) $=69.88-0.46 \times \mathrm{R}_{15 \mathrm{KHz}}$ ...(2.2)

Furthermore, the correlation between EMI readings at the three bands $(14,15$ and $16 \mathrm{KHz}$ ) and calculated ECc values from the above-mentioned equations were statistically analysed. These analyses showed that, there are an improvement in the obtained coefficient values by using $E_{\text {cs1 }}$ and $E_{\text {cs2 }}$ calculated from equations (1.1) and (1.2) for the surface and subsurface layer respectively. These coefficients for the surface layer were became $-0.823^{\star *},-0.882^{\star *}$ and $-0.823^{\star *}$ at the three bands $(14,15$ and $16 \mathrm{KHz})$ respectively. Also, these coefficients for the subsurface layer were improved to $0.805^{\star *},-0.867^{* *}$ and $-0.808^{* *}$ at these three bands respectively.

Moreover, the highest coefficient value of $\left(-1.0^{* *}\right)$ was obtained by using $\mathrm{EC}_{\mathrm{CS} 1}$ and $E_{\text {cs2 }}$ calculated from equations (2.1) and (2.2) that based on the band $15 \mathrm{KHz}$ alone for each of the two layers.

Finally, it could be concluded that, the using of equations (2.1) and (2.2) that based on the reading of EMI instrument at frequency band $15 \mathrm{KHz}$ alone was suitable for calculating salinity (ECc) of each surface and subsurface layer in the studied saline calcareous soil (Part, 1).

Produced spatial salinity distribution maps for the surface layer of Part (1) based on each of: lab determined ECe, calculated $\mathrm{EC}_{\mathrm{cs} 1}$ from eq. (2.1) and EMI readings at $15 \mathrm{KHz}$ are shown in Figs (5). to (7) respectively. The spatial salinity distribution maps for the subsurface layer of Part (1) based on each of: lab determined $\mathrm{ECe}$, and calculated $\mathrm{EC}_{\mathrm{cs} 2}$ from eq. (2.2) are shown in Figs (8) and (9) respectively.

Producing the salinity maps of nonsaline calcareous soils (Part, 2):

The statistical analyses for the results of Part (2) indicated that, there are a highly significant correlation coefficients between EMI readings at the three frequency bands and the lab determined ECe values of each layer. The coefficients of the surface layer were $0.675^{\star *}, 0.683^{* *}$ and $0.606^{\star *}$ with bands 14,15 and $16 \mathrm{KHz}$ respectively. The highest coefficient $\left(0.683^{\star *}\right)$ for this layer was found at band $15 \mathrm{KHz}$. In addition, the coefficients of the subsurface layer were $0.535^{* *}, 0.622^{* *}$ and $0.575^{\star *}$ for bands 14,15 and $16 \mathrm{KHz}$ respectively. Also, the highest coefficient 
for the subsurface layer $\left(0.622^{* *}\right)$ was

found at band $15 \mathrm{KHz}$.

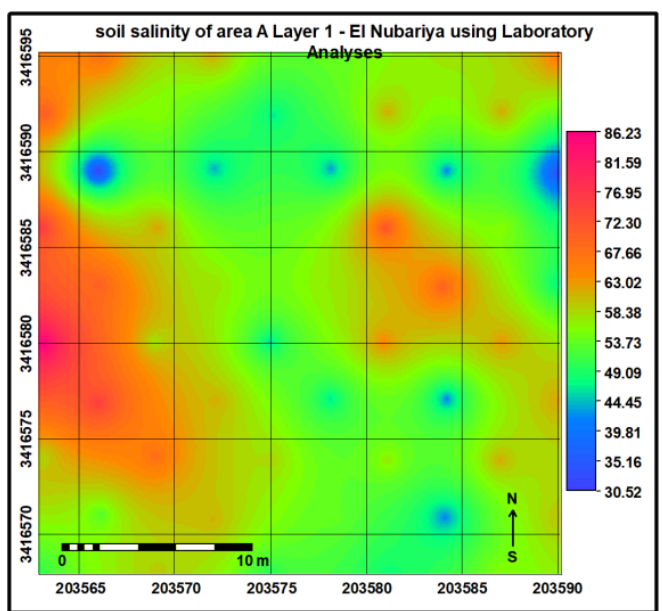

Fig (5): Spatial salinity map for surface layer of Part (1) based on lab ECe values.

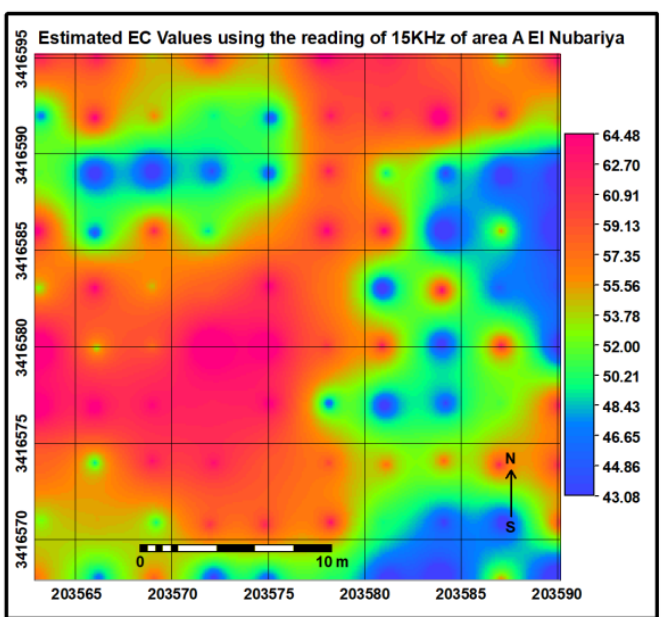

Fig (6): Spatial salinity map for surface layer of Part (1) based on EC cs1 from eq. (2.1).

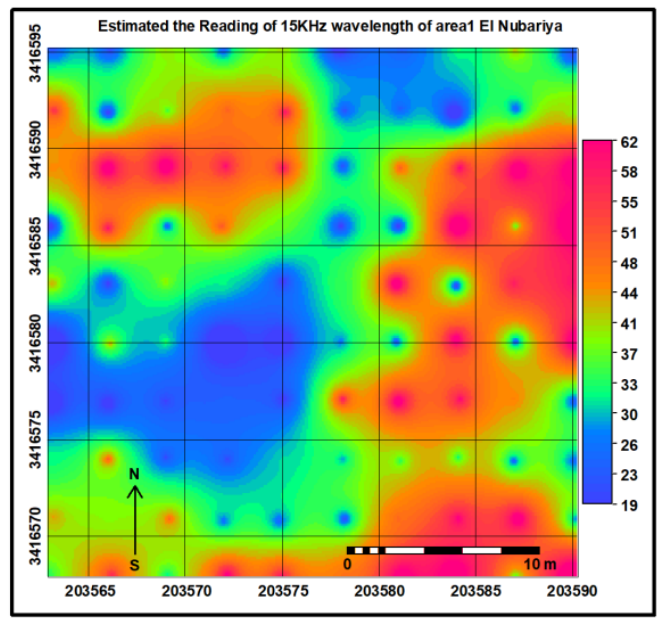

Fig. (7): Spatial distribution map of EMI readings at $15 \mathrm{KHz}$ alone for Part (1). 


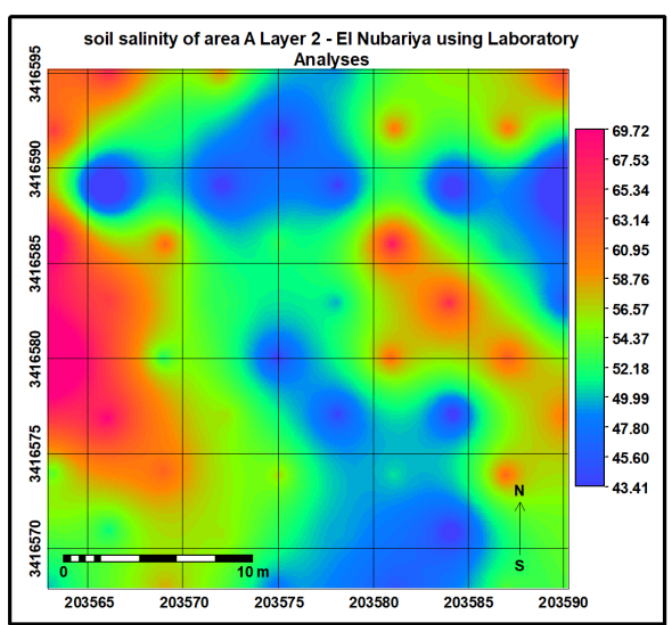

Fig (8): Spatial salinity map for subsurface layer of Part (1) based on lab ECe values.

Furthermore, four regression equations had educed to calculate soil salinity (ECC) by using the readings of EMI instrument for each layer of this Part (2). The first two equations (1.3) and (1.4) are multi factorial equations based on the three EMI readings at the three bands (14, 15 and $16 \mathrm{KHz}$ ) for each layer as follows:

ECcs1 $($ Part, 2$)=2.94+0.03 \times R 14 \mathrm{KHz}+$
$0.03 \times \mathrm{R} 15 \mathrm{KHz}+0.01 \times \mathrm{R} 16 \mathrm{KHz} \ldots . .(1.3)$

ECcs2 $($ Part, 2) $=4.03+0.003 \times R 14 K H z+$ $0.05 \times R 15 \mathrm{KHz}+0.03 \times \mathrm{R} 16 \mathrm{KHz} \ldots . .(1.4)$

The second equations (2.3) and (2.4) are simple regression equations based on EMI reading at band $15 \mathrm{KHz}$ alone for each layer as follows:

ECcs1 (Part, 2) = 33.03 - 0.06×R15KHz (2.3)

ECcs2 $($ Part, 2$)=3.37-0.07 \times R 15 K H z$

Moreover, the correlation between EMI readings at the three bands $(14,15$ and 16 $\mathrm{KHz}$ ) and calculated ECc values from the above-mentioned equations were statistically analysed. These analyses showed that, there are an improvement in the obtained coefficient values by using $E C_{c s 1}$ and $E_{\text {cs2 }}$ calculated from equations (1.3) and (1.4) for the surface and subsurface layer respectively. These coefficients for the surface layer were became $0.905^{\star *}, 0.911^{\star *}$ and $0.752^{\star *}$ at the

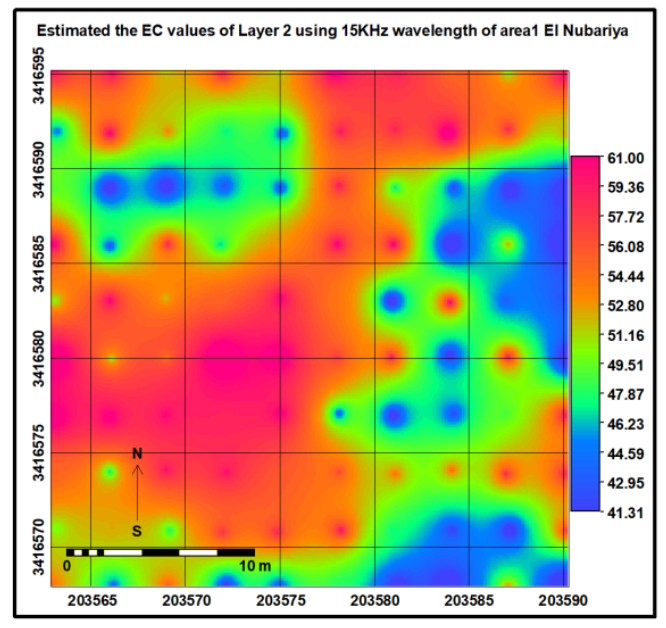

Fig (9): Spatial salinity map for subsurface layer of Part (1) based on EC cs2 from eq. (2.2).

three bands $(14,15$ and $16 \mathrm{KHz})$ respectively. Also, these coefficients for the subsurface layer were improved to $0.778^{\star *}, 0.937^{\star *}$ and $0.802^{\star *}$ at these three bands respectively.

On the other hand, the highest coefficient value of $\left(1.0^{* *}\right)$ was obtained by using $\mathrm{EC}_{\mathrm{cs} 1}$ and $\mathrm{EC}_{\mathrm{cs} 2}$ calculated from equations (2.3) and (2.4) that based on the band $15 \mathrm{KHz}$ alone for each of the two layers.

Finally, it could be concluded that, the using of equations (2.3) and (2.4) that based on the reading of EMI instrument at frequency band $15 \mathrm{KHz}$ alone was suitable for calculating salinity (ECc) of each surface and subsurface layer in the studied non-saline calcareous soil (Part, 2).

Produced spatial salinity distribution maps for the surface layer of Part (2) based on each of: lab determined ECe, calculated $E_{\mathrm{cs} 1}$ from eq. (2.3) and EMI readings at $15 \mathrm{KHz}$ are shown in Figs (10) to (12) respectively. The spatial salinity distribution maps for the subsurface layer of Part (2) based on each of: lab determined $\mathrm{ECe}$, and calculated $\mathrm{EC}_{\mathrm{cs} 2}$ from eq. (2.4) are shown in Figs (13) and (14) respectively. 
Producing the salinity maps of EI Sadat sandy soils (Part, 3):

The statistical analyses for the results of Part (3) indicated that, there are a highly significant correlation coefficients between EMI readings at the three frequency bands and the lab determined ECe values of each layer. The coefficients of the surface layer were $0.747^{* *}, 0.982^{* *}$ and $0.622^{\star *}$ for bands 14,15 and $16 \mathrm{KHz}$ respectively. It could be noticed that, the highest coefficient for the surface layer $\left(0.982^{\star *}\right)$ was found with band $15 \mathrm{KHz}$. In addition, the coefficients of the subsurface layer were $0.685^{\star *}, 0.968^{\star *}$ and $0.596^{\star *}$ for bands 14,15 and $16 \mathrm{KHz}$ respectively. Also, the highest coefficient

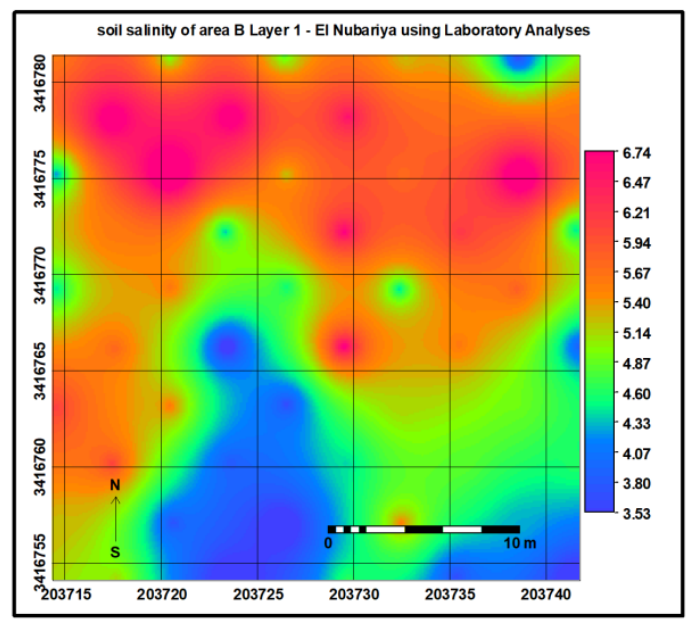

Fig (10): Spatial salinity map for surface layer of Part (2) based on lab ECe values. $\left(0.968^{\star *}\right)$ for the subsurface layer was found at band $15 \mathrm{KHz}$.

Moreover, four regression equations had educed to calculate soil salinity (ECC) by using the readings of EMI instrument for each layer of this Part (3). The first two equations (1.5) and (1.6) are multi factorial equations based on the three EMI readings at the three bands $(14,15$ and 16 $\mathrm{KHz}$ ) for each layer as follows:

$$
\begin{gathered}
\mathrm{EC}_{\mathrm{cs} 1}(\mathrm{Part}, 3)=0.48+0.19 \times \mathrm{R}_{14 \mathrm{KHz}}+ \\
0.91 \times \mathrm{R}_{15 \mathrm{KHz}}+0.05 \times \mathrm{R}_{16 \mathrm{KHz}} \ldots . \\
(1.5) \\
\mathrm{EC}_{\mathrm{cs} 2}(\text { Part, } 3)=0.37-0.03 \times \mathrm{R}_{14 \mathrm{KHz}}+ \\
0.83 \times \mathrm{R}_{15 \mathrm{KHz}}+0.04 \times \mathrm{R}_{16 \mathrm{KHz}} \ldots . \\
(1.6)
\end{gathered}
$$

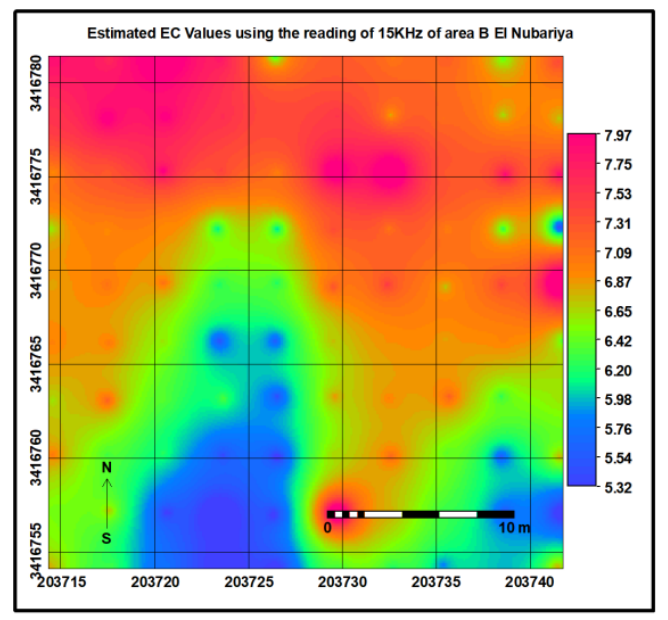

Fig (11): Spatial salinity map for surface layer of Part (2) based on EC $\mathrm{Cs}_{1}$ from eq. (2.3).

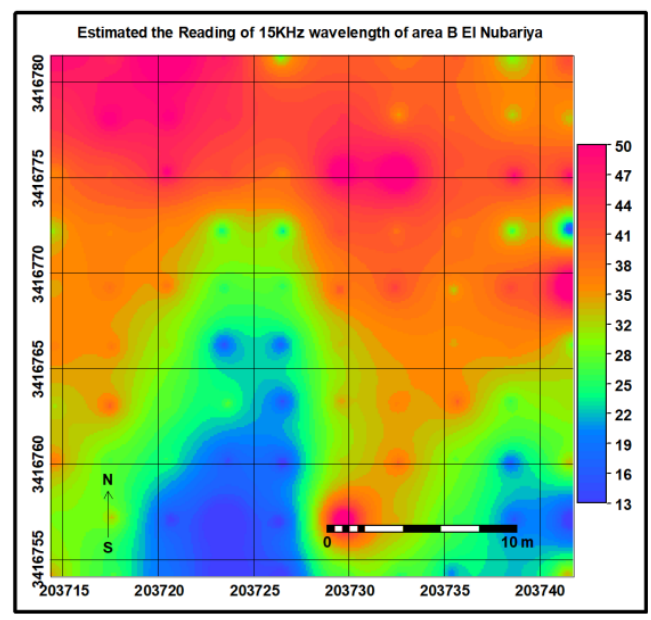

Fig. (12): Spatial distribution map of EMI readings at $15 \mathrm{KHz}$ alone for Part (2). 


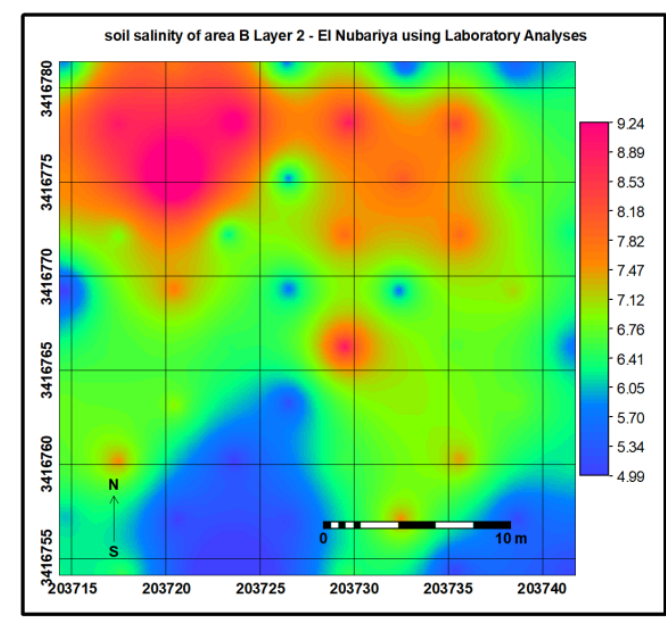

Fig (13): Spatial salinity map for subsurface layer of Part (2) based on lab ECe values.

The second equations (2.5) and (2.6) are simple regression equations based on EMI reading at band $15 \mathrm{KHz}$ alone for each layer as follows:

$\mathrm{EC}_{\mathrm{cs} 1}\left(\right.$ Part, 3) $=0.55+0.99 \times \mathrm{R}_{15 \mathrm{KHz}} \ldots$. (2.5)

$\mathrm{EC}_{\mathrm{cs} 2}\left(\right.$ Part, 3) $=0.39+0.83 \times \mathrm{R}_{15 \mathrm{KHz}} \ldots$. (2.6)

Furthermore, the correlation between EMI readings at the three bands $(14,15$ and $16 \mathrm{KHz}$ ) and calculated ECc values from the above-mentioned equations were statistically analyzed. These analyses showed that, there are an improvement in the obtained coefficient values by using $\mathrm{EC}_{\mathrm{cs} 1}$ and $\mathrm{EC}_{\mathrm{cs} 2}$ calculated from equations (1.5) and (1.6) for the surface and subsurface layer respectively. These coefficients for the surface layer were became $0.802^{\star *}, 0.996^{\star *}$ and $0.694^{\star *}$ at the three bands $(14,15$ and $16 \mathrm{KHz})$ respectively. Also, these coefficients for the subsurface layer were improved to $0.747^{\star *}, 1.00^{\star *}$ and $0.663^{\star *}$ at these three bands respectively.

On the other hand, the highest coefficient value of $\left(1.0^{* *}\right)$ was obtained by using $\mathrm{EC}_{\mathrm{cs} 1}$ and $\mathrm{EC}_{\mathrm{cs} 2}$ calculated from

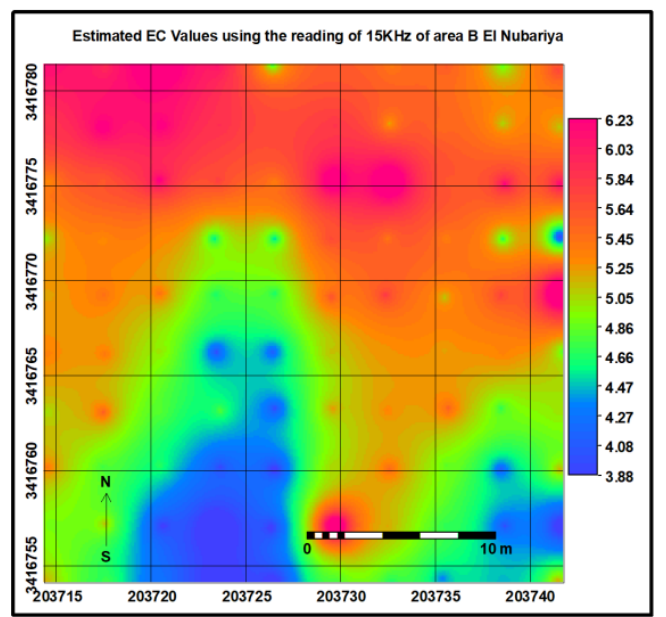

Fig (14): Spatial salinity map for subsurface layer of Part (2) based on EC cs2 from eq. (2.4).

equations (2.5) and (2.6) that based on the band $15 \mathrm{KHz}$ alone for each of the two layers.

Finally, it could be concluded that, the using of equations (2.5) and (2.6) that based on the reading of EMI instrument at frequency band $15 \mathrm{KHz}$ alone was suitable for calculating the salinity (ECc) for each surface and subsurface layer of the studied Part (3) in El Sadat sandy soils.

Produced spatial salinity distribution maps for the surface layer of Part (3) based on each of: lab determined ECe, calculated $E_{\mathrm{cs} 1}$ from eq. (2.5) and $E M I$ readings at $15 \mathrm{KHz}$ are shown in Figs (15) to (17) respectively. The spatial salinity distribution maps for the subsurface layer of Part (3) based on each of: lab determined $\mathrm{ECe}$, and calculated $\mathrm{EC}_{\mathrm{cs} 2}$ from eq. (2.6) are shown in Figs (18) and (19) respectively.

\section{REFERENCES}

Abou EI Nour, W. M. (2020). Pedochemical studies on desertic soils of El Sadat city and Noubaria using spectral reflectance. Ph.D. Thesis, Soil Sci. Dept., Fac. Agric. Menoufia Univ.

Burt, Rebecca, Ed. (2004). Soil Survey Laboratory Methods manual, soil 
Survey Investigations Report No. 42. V. 4, Natural Resources Conservation Service (NRCS) - USDA, Lincoln, Nebraska.

Martini, E., U. Werban, S. Zacharias, M. Pohle, P. Dietrich and U. Wollschläger (2017). Repeated electromagnetic induction measurements for mapping soil moisture at the field scale: validation with data from a wireless soil moisture monitoring network, Hydrol. Earth Syst. Sci., 21, 495-513, https://doi.orgl 10.5194/hess-21-4952017, 2017.

Priori, S.A., E.B. Martini and E.A.C.A. Costantini (2010). Three proximal sensors for mapping skeletal soils in vineyards" (c) 2010 19th World Congress of Soil Science, Soil
Solutions for a Changing World, 1 - 6 August 2010, Brisbane, Australia.

Saksa, P. and J. Sorsa (2016). "Geophysical Electromagnetic Measurements for Mine Site Groundwater Monitoring", Proceedings IMWA 2016, Freiberg/ Germany | Drebenstedt, Carsten, Paul, Michael (eds.) | Mining Meets Water Conflicts and Solutions.

Wollenhaupt, N. C., J. L. Richardson, J. E. Foss and E. C. Doll (1986). A rapid method for estimating weighted soil salinity from apparent soil electrical conductivity measured with an aboveground electromagnetic induction meter, Can. J. Soil Sci. 66: 315-321.

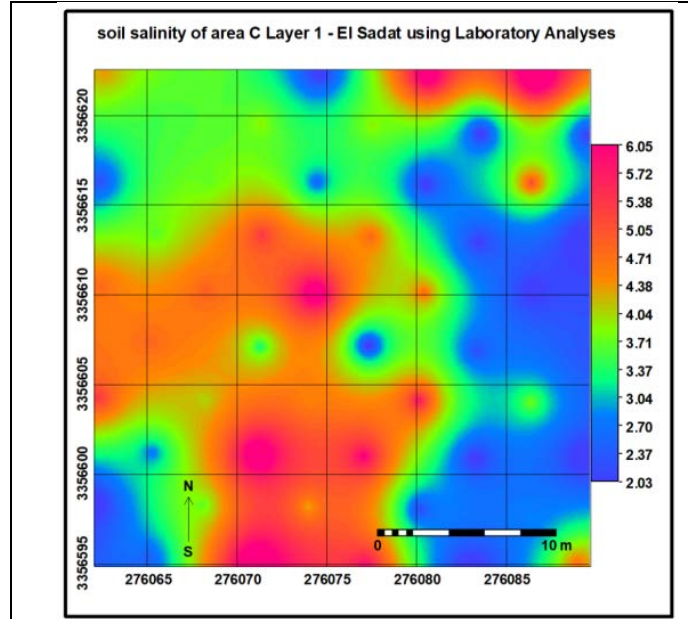

Fig (15): Spatial salinity map for surface layer of Part (3) based on lab ECe values.

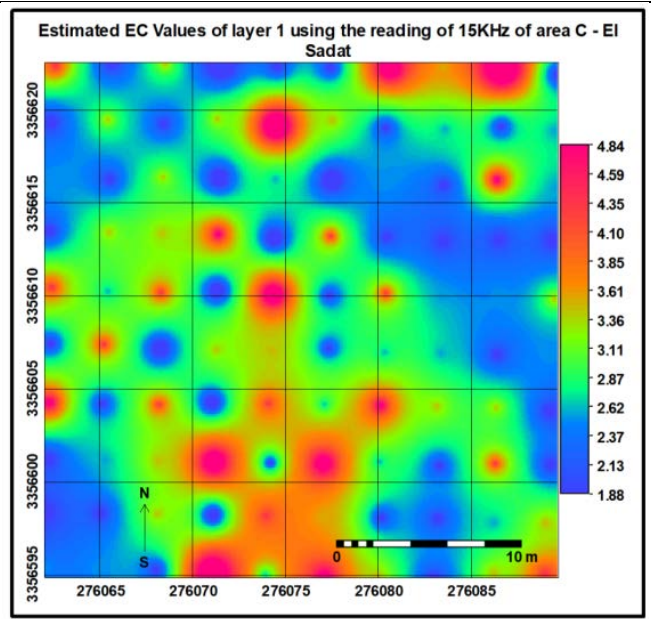

Fig (16): Spatial salinity map for surface layer of Part (3) based on EC cs1 $_{1}$ from eq. (2.5). 


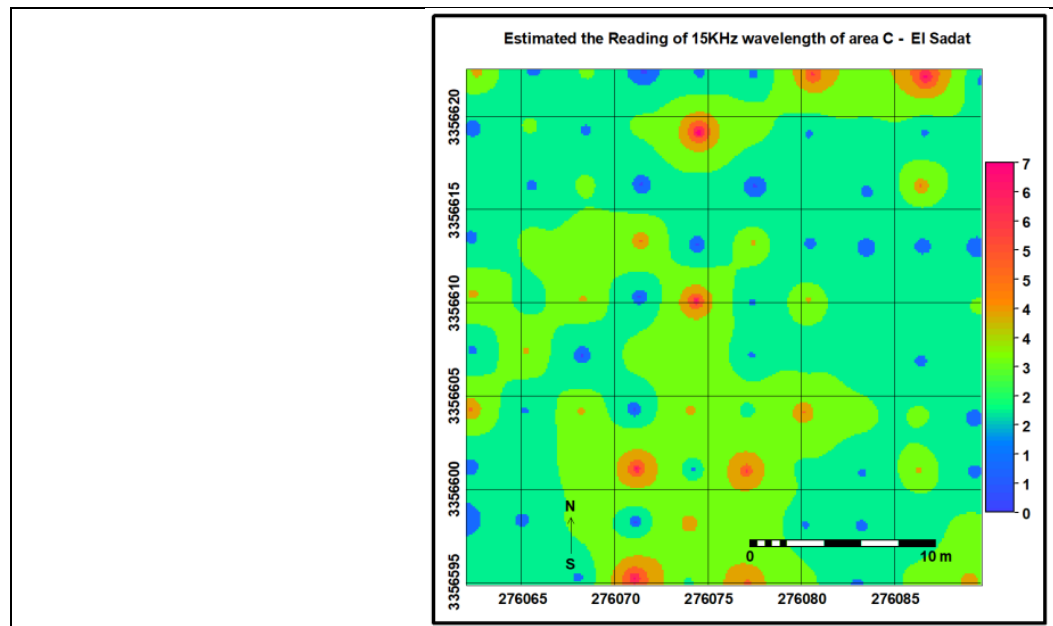

Fig (17): Spatial distribution map of EMI readings at $15 \mathrm{KHz}$ alone for Part (3).

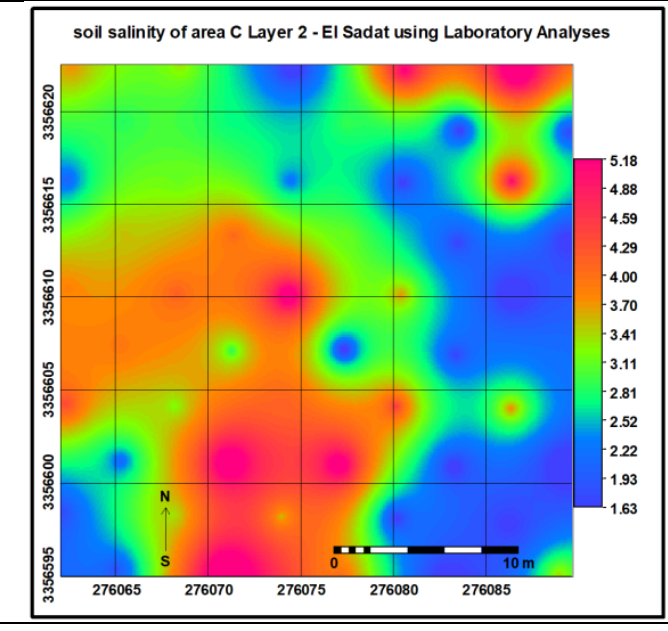

Fig (18): Spatial salinity map for subsurface layer of Part (3) based on lab ECe values.

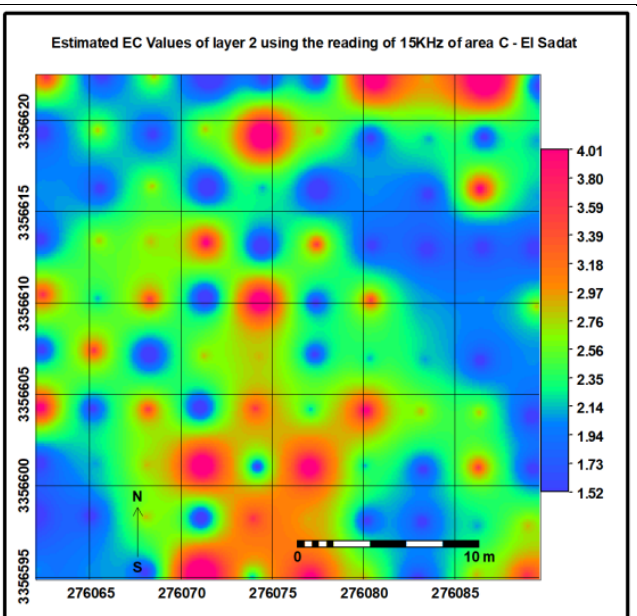

Fig (19): Spatial salinity map for subsurface layer of Part (3) based on ECcs2 from eq. (2.6).

\section{تقدير وإنتاج خرائط توزيع ملوحة التربة في بعض الأراضي المصرية بالاستعانة بجهاز الحث الكهرومغناطيسي}

رأفت كمال يعقوب(")، محمد سمير عراقي عميرة(†)، فوزى الثاذلي أبو عجوة(†)،

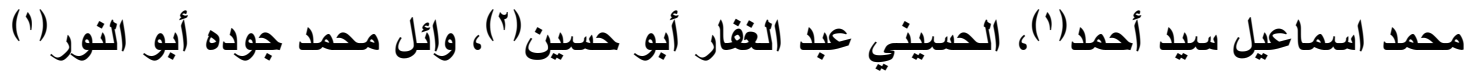

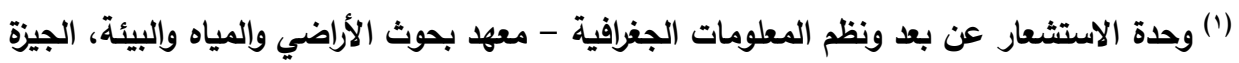
(() قسم علوم الأراضي - كلية النزاعة - جامعة المنوفية الجنية

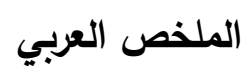

حليثاً يتم الاستعانة بتقنيات الاستشعار من بعد مثل أجهزة الحث الكهرومغناطيسي (EMI)، والمقاومة الكهربائية لاراسة ملوحة التربة، وعمق مستوي الماء الأرضي، ودراسة معادن التربة في الحقل، واستخام أجهزة الحث الكهرومغناطيسي الكئي 
هو وسيلة مفيدة لتقييم ملوحة التربة في المساحات الكبيرة، خاصة بعد معايرتها في أنواع مختلفة من التربة، ويهذف هذا البحث إلى تقدير وإنتاج خرائط توزيع ملوحة التربة لبعض الأراضي المصرية باستخدام جهاز الحث

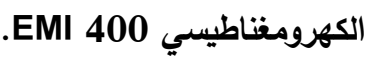

ولإجراء هذه الاراسة تم اختيار ثلاثة مساحات من الأراضي الجيرية الملحية وغير الملحية في منطقة النوبارية، والأراضي

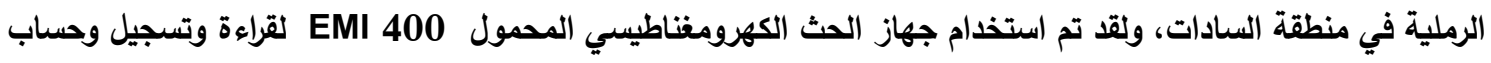

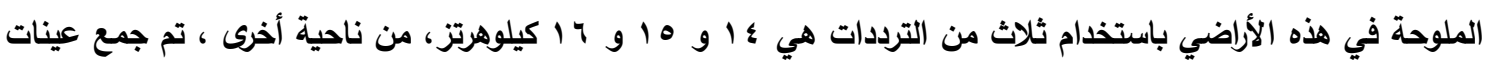

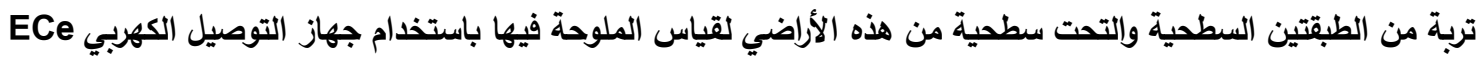

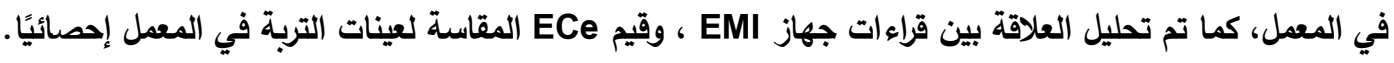

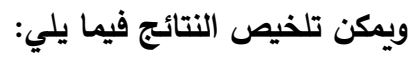

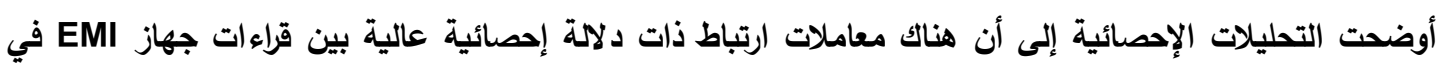

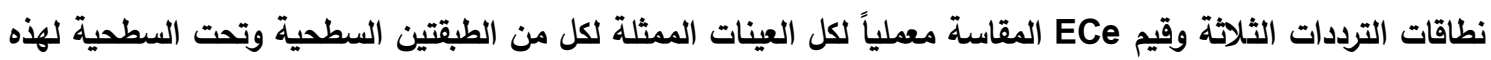

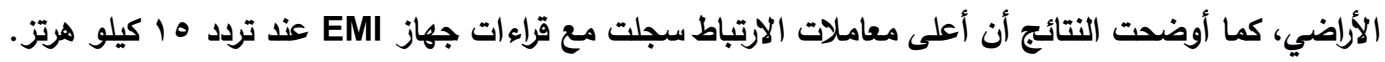

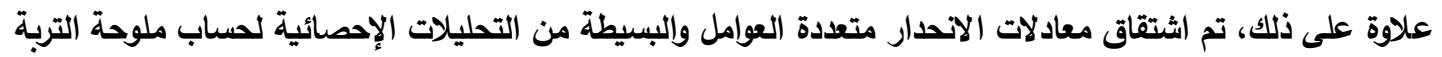
من قراءات جهاز EMI في مجال الترددات المختلفة، وكانت المعادلة الأسب لحساب ملوحة التربة ECc (ECc)

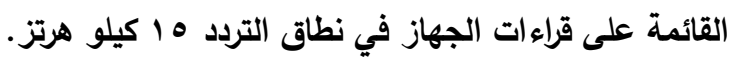

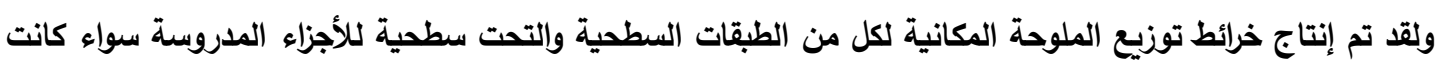

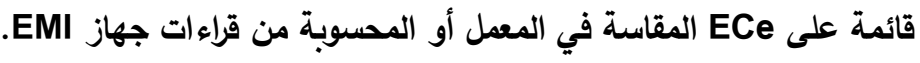

السادة المحكمين أ.د/ ممدوح خليل عبدالغةـــــار مركز البحوث الزراعيةـــ الجيزة أ.د/ صلاح عبد المجيد رضوان كلية الزراعة - جامعة المنوفية 